\title{
Cadmium (Cd) Absorption and Phenol Content in Pogostemon Exposed to Heavy Metals
}

\author{
Elly Proklamasiningsih *, Iman Budisantoso, Kamsinah
}

Faculty of Biology, Jenderal Soedirman University, Purwokerto, Indonesia

\begin{abstract}
Patchouli (Pogostemon cablin Benth.) is an important plant used by industrial facilities to absorb cadmium (Cd) in polluted land. We performed an experiment using plant medium polluted with both $\mathrm{Cd}$ and lead $(\mathrm{Pb})$ with added humic acid. The aims of this study were to 1 ) determine the effects of humic acid in growth medium contaminated with $\mathrm{Cd}$ and $\mathrm{Pb}$ on the absorption of $\mathrm{Cd}$ and phenol content in patchouli, and 2) determine the Cd tolerance level of the growth media. A completely randomized factorial design was used for the experiment with two factors. The heavy metals were a combination of pure $\mathrm{PbNO}_{3}$ and $\mathrm{Cd}(\mathrm{PC})$ with a ratio $1: 1$, and included five concentrations: PCo (without $\mathrm{PbNO}_{3}$ and without Cd); PC1 (250 ppm $\mathrm{PbNO}_{3}+250 \mathrm{ppm} \mathrm{Cd}$ ); PC2 (500 ppm $\mathrm{PbNO}_{3}+500$ ppm $\mathrm{Cd})$; $\mathrm{PC} 3$ (750 ppm $\mathrm{PbNO}_{3}+750$ ppm Cd); PC4 (1,000 ppm $\mathrm{PbNO}_{3}+1,000 \mathrm{ppm} \mathrm{Cd}$ ) and humic acid concentration $(0 ; 6,000 ; 12,000$; and 18,000 ppm). Each treatment was replicated three times. The parameters observed were plant biomass, Cd absorption, and phenol content. The application rate of humic acid to the plant medium containing heavy metals influenced the growth of patchouli, Cd absorption, and phenol content. An application rate of 12,000 ppm of humic acid reduced the toxicity of the heavy metals and increased the dry biomass and phenol content of patchouli.
\end{abstract}

Keywords: Cadmium, humic acid, phenol, Pogostemon

\section{INTRODUCTION}

Cultivated on contaminated metal land given this patchouli (Pogostemon cablin Benth.). Is an industrial plant as a producer of essential oil (patchouly oil). This plant is widely cultivated in Sumatra, specially in Aceh, North Sumatra and West Sumatra. P. cablin is known as Aceh patchouli which has high productivity. Until now there is no information about the influence of heavy metals on patchouli growth, therefore researchers conducted this experiment. Experiments to use heavy metals in patchouli plant is done because this plant is an industrial plant that is not consumed orally, so it is expected this plant can be plant has a good prospect as a producer of patchouli oil.

Soil heavy metal contamination can affect human health if the soil is planted with crops. Soil contamination caused by heavy metals cannot be avoided, especially near waste disposal sites, since contamination can originate from waste that contains dangerous heavy metals. In addition, in open dumping waste disposal sys-

\footnotetext{
${ }^{*}$ Corresponding author:

Elly Proklamasiningsih

Faculty of Biology, Jenderal Soedirman University

Jalan Dr. Soperano No 63, Purwokerto, Indonesia 53122

E-mail: elly.proklamasi@gmail.com
}

tems, runoff water can contaminate the surrounding soil. The most common heavy metals found in contaminated soil are cadmium $(\mathrm{Cd})$, lead $(\mathrm{Pb})$, and chromium (Cr) [1]. Intensive care is required to amend soil contaminated with heavy metals.

Heavy metal contamination disturbs plant metabolic processes [2, 3]. Little physiological research, such as studies on absorbed particles, transportation inside the plant, and the extent of absorption through a carrier, has been reported. Plant species have different sensitivities and exhibit different abilities to accumulate heavy metals. One study found that $\mathrm{Cd}$ could obstruct glutamine synthesis and inhibited glutamine synthetase activity and stimulated glutamate dehydrogenase one in order to tolerate cadmium stress [4]. Another study observed the accumulation of cadmium in wheat shoots, roots and glumes could be inhibited by chlorimuronethyl to some extent after exposure to $1000 \mathrm{mg} / \mathrm{kg} \mathrm{Cd}$ [5].

The toxicity of metals in soil can be reduced by

\section{How to cite:}

Proklamasiningsih E, Budisantoso I, Kamsinah (2018) Cadmium (Cd) Absorption and Phenol Content in Pogostemon Exposed to Heavy Metals. J. Trop. Life. Science 8 (1): $6-10$. 
amending the soil with organic material $[6,7]$ such as humic acid [8, 9]. Humic acid is a polyelectrolytic macromolecule with $-\mathrm{COOH}$ and $-\mathrm{OH}$ functional groups; therefore, it can form complexes with metal ions [10], and is a final form of organic decomposition into acidbase-soluble fractions. Several studies [11, 12] found that application of humic acid to planting medium containing $\mathrm{Pb}, \mathrm{Cu}$, and $\mathrm{Mn}$ increased the metal content of corn.

Several plants can absorb and accumulate $\mathrm{Cd}$ in individual organs. For example, Bolboschoenus maritimus (L.) pepper accumulates the highest $\mathrm{Cd}$ concentration in its rhizomes, whereas Salix accumulates the highest Cd concentration in its leaves and stems [12]. One report showed that Pistia stratiotes could absorb $\mathrm{Pb}$ concentrations of up to $10 \mathrm{mg} / \mathrm{kg}$ [13].

The present study examined patchouli ( $P$ cablin Benth), which is an industrial plant with high economic value and high prospects development of Patchouli alcoho because it is a producer of an essential oil, known as patchouli oil [14]. Essential oils contain phenol compounds, most of which are derived from free eugenols, some eugenol acetates, and sesquiterpenes, as well as small amounts of esters, ketones, and alcohols. Patchouli oil is used widely in the cosmetics and perfume industry. The purpose of this research was to determine the effects of amending soil contaminated with $\mathrm{Cd}$ and $\mathrm{Pb}$ with humic acid on the $\mathrm{Cd}$ absorption and phenol content of patchouli, and to determine the highest metal concentration of the planting medium that can be tolerated by patchouli.

\section{MATERIALS AND METHODS}

\section{Planting medium preparation}

The planting medium used in this study was soil passed through a $2-\mathrm{mm}$ sieve containing various humic acid and heavy metal concentrations.

The heavy metals were a combination of pure $\mathrm{PbNO}_{3}$ and $\mathrm{Cd}$ (PC) with a ratio 1:1, and included five concentrations:

1. $\mathrm{PC0}$ (without $\mathrm{Pb} \mathrm{NO} 3$ and without $\mathrm{Cd}$ );

2. $\mathrm{PC} 1(250 \mathrm{ppm} \mathrm{PbNO} 3+250 \mathrm{ppm} \mathrm{Cd})$;

3. $\mathrm{PC} 2(500 \mathrm{ppm} \mathrm{PbNO} 3+500 \mathrm{ppm} \mathrm{Cd})$;

4. $\mathrm{PC} 3(750 \mathrm{ppm} \mathrm{PbNO} 3+750 \mathrm{ppm} \mathrm{Cd})$;

5. $\mathrm{PC} 4(1000$ ppm $\mathrm{PbNO} 3+1000$ ppm Cd)

The humic acid treatment included four concentrations: 0 ppm (H0); 6,000 ppm (H1); 12,000 ppm (H2), and $18,000 \mathrm{ppm}$ (H3). Distilled water was added to the planting medium until it reached field capacity, and was then wrapped in a polybag. Each polybag contained 5 $\mathrm{kg}$ of planting medium.

\section{Patchouli culturing and effect of planting medium}

Plant seedling cuttings originated from the first 30 $\mathrm{cm}$ of the stem and were directly planted in the medium after four weeks of treatment. The experiment was conducted in polybags that were $40 \mathrm{~cm}$ in height and $35 \mathrm{~cm}$ in diameter, with one plant per polybag. The parameters observed included plant biomass, Cd absorption in plant organs, and phenol content. The observations were performed when plants were 90 days old.

\section{Determination of $C d$ distribution in plants}

The Cd determination in plant was assayed according Hsu and Kao (2003) [15]. The plants were separated into two different parts, as roots and shoots. Both of them were dried at $80^{\circ} \mathrm{C}$ for 48 hours, and then ashed in Muffle furnace at $550^{\circ} \mathrm{C}$ for 20 hours. The ash residue was incubated with $31 \% \mathrm{HNO}_{3}$ and $17.5 \% \mathrm{H}_{2} \mathrm{O}_{2}$ at $75^{\circ} \mathrm{C}$ for 2 hours, and then dissolved in distilled water. The Cd concentration in the digest was determined using an atomic absorption spectrophoto-meter (AA6800, Shimadzu, Japan).

\section{Determination of phenol content}

The phenol content was determined using the Folin-Ciocalteau method [16]. The working principal of this extraction is that the measured compound (phenol) is dissolved in methanol. First, $2 \mathrm{~g}$ of patchouli leaves and stems were dipped into boiling alcohol for $3 \mathrm{~min}$, and then pulverized. Next, $1 \mathrm{~g}$ of homogenate was taken for extraction in $2.5 \mathrm{~mL}$ of $70 \%$ methanol using a rotary shaker. This process was repeated to optimize the amount of phenol compounds while minimizing the amount of sediment. The phenol extract was formed, set aside for a few minutes until sediment formed, and then centrifuged at 5,000 rpm for 10 minutes.

The phenol content of the extract was determined at an extract concentration of $1 \mathrm{mg} / \mathrm{mL}$. The reaction was made using $0.5 \%$ methanol-extracted compound, $2.5 \mathrm{~mL} \mathrm{10 \%} \mathrm{Folin-Ciocalteau} \mathrm{reagent} \mathrm{dissolved} \mathrm{in} \mathrm{water,}$ and $2.5 \mathrm{~mL}$ of $7.5 \% \mathrm{NaHCO}_{3}$. The blank consisted of $0.5 \mathrm{~mL}$ methanol, $2.5 \mathrm{~mL} \mathrm{10 \%}$ Folin-Ciocalteau reagent in water, and $2.5 \mathrm{~mL}$ of $7.5 \% \mathrm{NaHCO}_{3}$. The sample was incubated in an incubator at $45^{\circ} \mathrm{C}$ for 45 minutes. Absorbance was determined with a spectrophotometer at $\lambda$ $\max =765 \mathrm{~nm}$. Three samples were prepared for each treatment for the analysis and the average values were 
determined. The same procedure was repeated using gallic acid standard and the calibration curve was interpreted. Based on the measured absorbance, the phenolic content $(\mathrm{mg} / \mathrm{mL})$ was determined from the calibration curve; therefore, the phenol concentration inside the extract was stated in terms of gallic acid equivalent ( $\mathrm{mg}$ GAE/g extract).

\section{Experimental design}

This research uses experimental method with Completely Randomized Design (CRD) factorial pat-tern with two factors. $\mathrm{Cd}$ and $\mathrm{PbNO}_{3}$ concentrations (PC0; $\mathrm{PC} 1$; $\mathrm{PC}$; $\mathrm{PC} 3$; and $\mathrm{PC} 4)$ and humic acid concentration (H0; H1; H2; H3). Each combination of treatments was repeated three times.

\section{Statistical analysis}

Analysis of variance with Tukey's test was used for the statistical analysis in SPSS for Windows software.

\section{RESULTS AND DISCUSSION}

The results showed that the use of humic acid in planting medium exposed to heavy metals on nilam cuttings caused significant effect on root $\mathrm{Cd}$ concentration $(\mathrm{F}=1283.7 ; \mathrm{p}<0.00), \mathrm{Cd} \operatorname{rod}(\mathrm{F}=932.5 ; \mathrm{p}<0.00)$, leaf $\mathrm{Cd}(\mathrm{F}=773.1, \mathrm{P}<0.00)$ absorbed by plant and plant biomass $(\mathrm{F}=8,895 ; \mathrm{p}<0.00)$. Giving humic acid 12,000 $\mathrm{ppm}$ can reduce metal toxicity on exposed media $\mathrm{Pb}$ and Cd 500 ppm (H2PC2) concentration so that plant biomass is increased (Table 1).

The ability of patchouli to absorb Cd can be measured through the highest plant biomass and highest

Table 1. Plant biomass $(\mathrm{g})$ and Cd concentration in patchouli root, stem, and leaf $(\mathrm{mg} / \mathrm{kg})$ for each treatment

\begin{tabular}{|c|c|c|c|c|c|}
\hline \multirow{2}{*}{ No. } & \multirow{2}{*}{ Treatment } & \multicolumn{4}{|c|}{$\operatorname{Mean}( \pm S D)$} \\
\hline & & Biomass (g) & $C d($ root $)(\mathrm{mg} / \mathrm{kg})$ & $C d(\mathrm{stem})(\mathrm{mg} / \mathrm{kg})$ & $C d($ leaf $)(\mathrm{mg} / \mathrm{kg})$ \\
\hline 1. & HоPC0 & $29.96( \pm 0.63)$ fghi & $0.03( \pm 0.00) \mathrm{n}$ & $0.03( \pm 0.00) n$ & $0.02 \pm 0.001$ \\
\hline 2. & HoPC1 & $28.06( \pm 0.30)$ ghij & $0.07( \pm 0.00) \mathrm{j}$ & $0.04( \pm 0.00) \mathrm{m}$ & $0.02 \pm 0.00 \mathrm{j}$ \\
\hline 3. & HoPC2 & $26.70( \pm 0.10) h_{i j}$ & $0.08( \pm 0.00) \mathrm{h}$ & $0.05( \pm 0.00) \mathrm{j}$ & $0.03 \pm 0.00 \mathrm{gh}$ \\
\hline 4. & HoPC3 & $24.20( \pm 0.06) \mathrm{ij}$ & $0.09( \pm 0.00) \mathrm{g}$ & $0.06( \pm 0.00) \mathrm{h}$ & $0.04 \pm 0.00 \mathrm{e}$ \\
\hline 5. & $\mathrm{HoPC} 4$ & $22.09( \pm 0.08) \mathrm{j}$ & $0.09( \pm 0.00) \mathrm{f}$ & $0.06( \pm 0.00) \mathrm{h}$ & $0.05 \pm 0.00 \mathrm{c}$ \\
\hline 6. & H1PC0 & $38.11( \pm 0.29) \mathrm{cde}$ & $0.03( \pm 0.00) \mathrm{m}$ & $0.03( \pm 0.00) \mathrm{n}$ & $0.02 \pm 0.001$ \\
\hline 7. & H1PC1 & $37.42( \pm 0.05) \mathrm{cde}$ & $0.06( \pm 0.00) \mathrm{k}$ & $0.05( \pm 0.00) 1$ & $0.03 \pm 0.00 \mathrm{~h}$ \\
\hline 8. & H1PC2 & $35.92( \pm 0.25)$ cdef & $0.09( \pm 0.00) \mathrm{g}$ & $0.05( \pm 0.00) 1$ & $0.03 \pm 0.00 \mathrm{f}$ \\
\hline 9. & H1PC3 & $33.64( \pm 0.16) \mathrm{defg}$ & $0.09( \pm 0.00) \mathrm{f}$ & $0.05( \pm 0.00) \mathrm{k}$ & $0.04 \pm 0.00 \mathrm{~d}$ \\
\hline 10. & $\mathrm{H} 1 \mathrm{PC} 4$ & $28.11( \pm 7.87)$ ghij & $0.10( \pm 0.00) \mathrm{d}$ & $0.08 \pm 0.00 \mathrm{e}$ & $0.05 \pm 0.00 \mathrm{a}$ \\
\hline 11. & $\mathrm{H} 2 \mathrm{PC} 0$ & $45.90( \pm 0.58) \mathrm{a}$ & $0.03( \pm 0.00) \mathrm{mn}$ & $0.03 \pm 0.00 \mathrm{n}$ & $0.02 \pm 0.001$ \\
\hline 12. & $\mathrm{H} 2 \mathrm{PC} 1$ & $35.97( \pm 8.69) \mathrm{cdef}$ & $0.06( \pm 0.00) 1$ & $0.05 \pm 0.00 \mathrm{jk}$ & $0.02 \pm 0.00 \mathrm{jk}$ \\
\hline 13. & $\mathrm{H} 2 \mathrm{PC} 2$ & $39.96( \pm 0.60) \mathrm{abcd}$ & $0.11( \pm 0.00) \mathrm{c}$ & $0.08 \pm 0.00 \mathrm{c}$ & $0.05 \pm 0.00 \mathrm{~b}$ \\
\hline 14. & $\mathrm{H} 2 \mathrm{PC} 3$ & $38.68( \pm 0.55)$ bcde & $0.10( \pm 0.00) \mathrm{e}$ & $0.06 \pm 0.00 \mathrm{i}$ & $0.05 \pm 0.00 \mathrm{a}$ \\
\hline 15. & $\mathrm{H} 2 \mathrm{PC} 4$ & $38.42( \pm 0.46) \mathrm{cde}$ & $0.11 \pm 0.00 b$ & $0.08 \pm 0.00 \mathrm{~b}$ & $0.03 \pm 0.00 \mathrm{i}$ \\
\hline 16. & Н3РС0 & $45.03( \pm 0.45) \mathrm{ab}$ & $0.03 \pm 0.00 \mathrm{~m}$ & $0.03 \pm 0.00 \mathrm{n}$ & $0.02 \pm 0.00 \mathrm{~m}$ \\
\hline 17. & H3PC1 & $41.28 \pm 0.24 \mathrm{abc}$ & $0.08 \pm 0.00 \mathrm{i}$ & $0.09 \pm 0.47 \mathrm{a}$ & $0.02 \pm 0.00 \mathrm{k}$ \\
\hline 18. & Н3РC2 & $33.05 \pm 9.66 \mathrm{efgh}$ & $0.09 \pm 0.00 \mathrm{f}$ & $0.08 \pm 0.00 \mathrm{~d}$ & $0.03 \pm 0.00 \mathrm{i}$ \\
\hline 19. & Н3РC3 & $36.42 \pm 0.44 \mathrm{cde}$ & $0.10 \pm 0.00 \mathrm{~d}$ & $0.07 \pm 0.00 \mathrm{~g}$ & $0.03 \pm 0.00 \mathrm{~g}$ \\
\hline 20. & H3PC4 & $28.90 \pm 8.01 \mathrm{ghi}$ & $0.12 \pm 0.00 \mathrm{a}$ & $0.07 \pm 0.00 \mathrm{f}$ & $0.03 \pm 0.00 \mathrm{gh}$ \\
\hline
\end{tabular}

Note: - Means followed by the same letters are not as different for each treatment means $(\mathrm{p}<0.00)$.

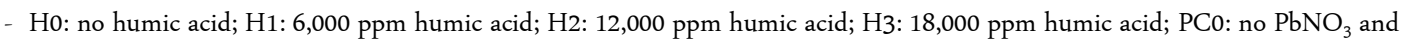
without Cd; PC1: 250 ppm $\mathrm{PbNO}_{3}+250$ ppm Cd; PC2: 500 ppm PbNO3 + 500 ppm Cd; PC3: 750 ppm PbNO3 + 750 ppm Cd; PC4: 1000 ppm Pb NO3 + 1000 ppm Cd 
Table 2. Patchouli stem and leaf phenolic content with humic acid and heavy metal addition

\begin{tabular}{|c|c|c|c|}
\hline \multirow{2}{*}{ No. } & \multirow{2}{*}{ Treatment } & \multicolumn{2}{|c|}{$\operatorname{Mean}( \pm S D)(\mathrm{mg} / \mathrm{mL})$} \\
\hline & & Stem phenol concentration & Leaf phenol concentration \\
\hline 1. & HoPC0 & $0.10( \pm 0.01) \mathrm{i}$ & $0.18( \pm 0.01) \mathrm{g}$ \\
\hline 2. & HoPC1 & $0.06( \pm 0.01) \mathrm{k}$ & $0.11( \pm 0.01) \mathrm{j}$ \\
\hline 3. & HoPC2 & $0.05( \pm 0.01) 1$ & $0.09( \pm 0.01) \mathrm{k}$ \\
\hline 4. & HoPC3 & $0.04( \pm 0.01) \mathrm{lm}$ & $0.08( \pm 0.01) \mathrm{k}$ \\
\hline 5. & $\mathrm{HoPC} 4$ & $0.03( \pm 0.01) \mathrm{m}$ & $0.08( \pm 0.01) \mathrm{k}$ \\
\hline 6. & H1PC0 & $0.18( \pm 0.01) b c$ & $0.26( \pm 0.01) \mathrm{c}$ \\
\hline 7. & H1PC1 & $0.14( \pm 0.01) \mathrm{fg}$ & $0.17( \pm 0.01) \mathrm{g}$ \\
\hline 8. & $\mathrm{H} 1 \mathrm{PC} 2$ & $0.12( \pm 0.01) \mathrm{h}$ & $0.16( \pm 0.01) \mathrm{h}$ \\
\hline 9. & H1PC3 & $0.07( \pm 0.01) \mathrm{k}$ & $0.14( \pm 0.01) \mathrm{i}$ \\
\hline 10. & $\mathrm{H} 1 \mathrm{PC} 4$ & $0.06( \pm 0.01) \mathrm{k}$ & $0.10( \pm 0.01) \mathrm{j}$ \\
\hline 11. & $\mathrm{H} 2 \mathrm{PC} 0$ & $0.20( \pm 0.01) \mathrm{a}$ & $0.30( \pm 0.01) \mathrm{a}$ \\
\hline 12. & $\mathrm{H} 2 \mathrm{PC} 1$ & $0.17( \pm 0.01) \mathrm{cd}$ & $0.30( \pm 0.01) \mathrm{a}$ \\
\hline 13. & $\mathrm{H} 2 \mathrm{PC} 2$ & $0.16( \pm 0.01) \mathrm{de}$ & $0.30( \pm 0.01) \mathrm{a}$ \\
\hline 14. & $\mathrm{H} 2 \mathrm{PC} 3$ & $0.15( \pm 0.01)$ ef & $0.28( \pm 0.01) b$ \\
\hline 15. & $\mathrm{H} 2 \mathrm{PC} 4$ & $0.12( \pm 0.01) \mathrm{h}$ & $0.25( \pm 0.01) \mathrm{d}$ \\
\hline 16. & Н3РC0 & $0.18( \pm 0.01) b$ & $0.26( \pm 0.01) \mathrm{c}$ \\
\hline 17. & H3PC1 & $0.14( \pm 0.01) \mathrm{fg}$ & $0.22( \pm 0.01) \mathrm{e}$ \\
\hline 18. & Н3PC2 & $0.14( \pm 0.01) \mathrm{g}$ & $0.20( \pm 0.01) \mathrm{f}$ \\
\hline 19. & Н3РC3 & $0.11( \pm 0.01) \mathrm{hi}$ & $0.14( \pm 0.01) \mathrm{i}$ \\
\hline 20. & Н3РC4 & $0.09( \pm 0.01) \mathrm{j}$ & $0.11( \pm 0.01) \mathrm{j}$ \\
\hline
\end{tabular}

Note: - Means followed by the same letters are not as different for each treatment means $(\mathrm{p}<0.00)$.

- Ho: no humic acid; H1: 6,000 ppm humic acid; H2: 12,000 ppm humic acid; H3: 18,000 ppm humic acid PC0: no $\mathrm{PbNO}_{3}$ and without Cd; PC1: 250 ppm $\mathrm{PbNO}_{3}+250$ ppm Cd; PC2: 500 ppm $\mathrm{PbNO}_{3}+500$ ppm Cd; PC3: 750 ppm $\mathrm{PbNO}_{3}+750$ ppm Cd; PC4: $1000 \mathrm{ppm} \mathrm{PbNO}_{3}+1000 \mathrm{ppm} \mathrm{Cd}$

Cd concentration which can be translocated to leaf organ. In $\mathrm{H} 2 \mathrm{PC} 2$ it is evident that during the $\mathrm{Cd}$ translocation from the root organ to the leaf organ inside the xylem does not cause damage to the molecules present in the xylem.

Cd accumulated on the root, and only some was translocated to the leaves and stems (Table 1). This indicated that $\mathrm{Cd}$ had complexed with humic acid, reducing its mobility. Cd on the plant increased with increasing humic acid and heavy metal concentrations, probably due to the formation of chelates from humic acid. Humic compounds can effectively bind to certain elements. Metal absorption by plant systems occurs along with nutrient uptake from soil water. Although high concentrations of metals can be toxic to plants, humic acid addition can bind to such toxic metals in soil water [10].
Plants exposed to $\mathrm{Cd}$ and $\mathrm{Pb}$ in soil without humic acid amendment had lower biomasses. Amendment with $1,200 \mathrm{ppm}$ humic acid decreased the metal toxicity in the exposed medium to 1,000 ppm. Moreover, 1,200 ppm and 1,800 ppm humic acid increased the dry plant biomass and $\mathrm{Cd}$ concentration adsorbed on the root. It also decreased the metal toxicity threshold to $1000 \mathrm{ppm}$ $\mathrm{Cd} / \mathrm{Pb}$. These results indicated that chelates formed in the presence of humic acid. Humic compounds have been found to be very effective in binding to metals via complexation [17].

Table 2 presents the stem and leaf phenolic contents in plants exposed to heavy metals and humic acid. Treatments that resulted in higher phenol concentrations also resulted in high dry biomasses. Phenol biosynthesis begins with malonic acid and shikimate acid, while these 
compounds form from monosaccharides during photosynthesis. Therefore, high rates of photosynthesis result in high production of phenol as a secondary metabolite. Plant growth parameters can be used as response indicators for plants cultivated in contaminated planting medium. Application of 1,200 ppm humic acid can increase the leaf phenol concentrations of plants in medium contaminated with as much as $750 \mathrm{ppm} \mathrm{Cd} / \mathrm{Pb}$.

\section{CONCLUSION}

Applying humic acid to plant medium contaminated with heavy metals can affect $\mathrm{Cd}$ absorption, patchouli growth, and patchouli oil content. Application of 1,200 ppm humic acid can decrease heavy metal toxicity, thereby increasing the dry biomass and phenolic content of patchouli.

\section{ACKNOWLEDGMENT}

The authors would like to thank the LPPM Universitas Jenderal Soedirman, which funded this research through the Program Penelitian Fundamental in 2014.

\section{REFERENCES}

1. Li T, Cheng H, Oh K, Hosono S (2014) Effect of humic acid and bacterial manure on distribution of heavy metals in different organs of maize. International Journal of Environmental Science and Development 5 (4): 393 - 397. doi: 10.7763/IJESD.2014.V5.516.

2. Chen X, Wang J, Shi Y et al. (2011) Effects of cadmium on growth and photosynthetic activities in pakchoi and mustard. Botanical Studies 52 (1): $41-46$.

3. Gong X, Yin L, Chen J, Guo C (2015) Overexpression of the iron transporter NtPIC1 in tobacco mediates tolerance to cadmium. Plant Cell Reports 34 (11): 1963 - 1973. doi:10.1007/s00299-015-1843-4.

4. Afef NH, Houda G, Chiraz CH (2012) Response of Arabidopsis thaliana, seedlings to cadmium in relation to ammonium availability. Bulletin of Environmental Contamination and Toxicology 89 (6): 1175 - 1180. doi: 10.1007/s00128-012-0840-3.

5. Jin C, Zhou Q, Zhou Q, Fan J (2010) Effects of chlorimuronethyl and cadmium on biomass growth and cadmium accumulation of wheat in the phaiozem area, Northeast China. Bulletin of Environmental Contamination and Toxicology 84 (4): 395 - 400. doi: 10.1007/s00128-009-9635-6.

6. Saha JK, Panwar NR, Coumar MV (2013) Effect of methods of preparation on distribution of heavy metals in different size fractions of municipal solid waste composts. Environmental Monitoring and Assessment 185 (11): 8815 - 8821. doi: 10.1007/s10661-013-3214-3.

7. He XS, Xi BD, Li D et al. (2014) Influence of the composition and removal characteristics of organic matter on heavy metal distribution in compost leachates. Environmental Science and Pollution Research 21 (12): 7522 - 7529. doi: 10.1007/s11356-014-2674-5.

8. Sardashti A, Angtarash MH, Asadi A (2015) Defining the metal ions contaminants in the leaves and growing place soil of cultivated $A$. triphylla plant with addition of humic substances to root. International Journal of Agriculture and Crop Sciences 8 (2): 142 - 148.

9. Topcuoglu B (2013) Effects of humic acids on the phytoextraction efficiency of sludge applied soil. International of Chemical, Environmental and Biological Sciences 1 (1): 21 -24 .

10. Khaled H, Fawy HA (2011) Effect of different levels of humic acids on the nutrient content, plant growth, and soil properties under conditions of salinity. Soil and Water Research 6 (1): $21-29$.

11. Arancon NQ, Edwards CA, Lee S, Byrne R (2006) Effects of humic acids from vermicomposts on plant growth. European Journal of Soil Biology 42 (Supplement 1): S65 - S69. doi: 10.1016/j.ejsobi.2006.06.004.

12. Ling T, Jun R, Fangke Y (2011) Effect of cadmium supply levels to cadmium accumulation by Salix. International Journal of Environmental Science and Technology 8 (3): $493-$ 500. doi: 10.1007/BF03326235.

13. Proklamasiningsih E, Hernayanti H (2010) Rizofiltrasi logam $\mathrm{Pb}$ (Plumbum) pada beberapa jenis tumbuhan air. Biosfera $27(1): 30-37$.

14. Xu F, Yang Q, Wu L et al. (2017) Investigation of inclusion complex of patchouli alcohol with $\beta$-cyclodextrin. PloS One 12 (1): e0169578. doi: 10.1371/journal.pone.0169578

15. Hsu YT, Kao CH (2003) Role of abscisic acid in cadmium tolerance of rice (Oryza sativa L.) seedlings. Plant Cell Environmental 26 (6): 867 - 874. doi: 10.1046/j.13653040.2003.01018.x.

16. Stankovic MS (2011) Total phenolic content, flavonoid concentration and antioxidant activity of Marrubium peregrinum L. extracts. Kragujevac Journal of Science 33 (2011): 63 -72 .

17. Mastrángelo M, Afonso MDS, Ferrari L (2011) Cadmium toxicity in tadpoles of Rhinella arenarum in relation to calcium and humic acids. Ecotoxicology 20 (6): 1225 - 1232. doi: 10.1007/s10646-011-0667-4. 